Article

\title{
INDIGENOUS RESEARCH AS RESISTANCE ${ }^{1}$
}

\author{
ELAINE COBURN \\ American University of Paris and Centre d'Analyse et d'Intervention \\ Sociologiques (CADIS) -Ecole des Hautes Etudes en Sciences Sociales (EHESS). \\ Paris, France
}

Keywords

Capitalism, colonialism, decolonization, Indigenous research, résistance

\section{Biographical note}

Elaine Coburn is editor of Socialist Studies/Etudes Socialistes. She may be reached at ecoburn@aup.fr or coburn@stanfordalumni.org.

Indigenous research is a form of resistance to centuries of colonial domination. As such, Indigenous research is part of a much broader political, economic, cultural and spiritual project of Indigenous resurgence. As the well-known Sioux scholar Vine Deloria Jr. observed, for hundreds of years "whites have had unrestricted power to describe Indians any way they choose" $(1998,66)$, but Indigenous peoples are now reclaiming that power for themselves, including in university spaces. In the process, Indigenous research is transforming the social sciences, bringing new ways of being and knowing to the academy and undertaking research in ways that often challenge taken-for-granted Enlightenment models of research. From perspectives at once diverse and revealing important common ground, I consider the work of three Indigenous researchers here: scholar Aileen Moreton-Robinson, a Goenpul woman from Minjerribah, Quandamooka First Nation in Queensland, Australia, African-Canadian George Sefa Dei, who is a traditional chief in Ghana and Makere Stewart-Harawira, Waitaha, part of the New Zealand Maori diaspora in Canada. Two of the texts I refer to, by Dei and StewartHarawira, are in this issue of Socialist Studies/Etudes Socialistes. Each scholar underscores the ways that Indigenous scholarship raises fundamental questions for contemporary colonial relations and for mainstream social science, while playing an important role in broader processes of decolonization and Indigenous resurgence.

${ }^{1}$ I would like to thank George Sefa Dei, Maggie Kovach, Emma LaRocque, Aileen Moreton-Robinson, Makere Stewart-Harare and Rima Wilkes for exchanges that inform this paper, as well as for helpful comments on earlier drafts. 


\section{Decolonizing Research}

In her pathbreaking work, Decolonizing Methodologies (2004), Maori scholar Linda Tuhiwai Smith argues that scientific research has been implicated in the "worst excesses of colonialism." She observes that the "collective memory of imperialism has been perpetuated through the ways in which knowledge about indigenous peoples was collected, classified and then represented in various ways back to the West, and then, through the eyes of the West, back to those who have been colonized" (1-2). The collection and display of Indigenous bodies as 'curiosities' and later as 'artifacts' in museums is just one example of the violence, at once material and spiritual that (social) science has exercised upon Indigenous peoples. Indeed, through such social scientific practices, scholarly research participated and participates in the creation of the collective colonial imagination about the Indigenous 'other' as inferior, savage and doomed to disappear (see, for instance, LaRocque 2010, 55-72). At the same time, such "naming and claiming" of Indigenous experiences -and even, literally, bodies and body parts-is a way for colonizers to possess Indigenous peoples and experiences. This 'scientific' process, Tuhiwai-Smith contends, is part of the same movement of dispossession as the "naming and claiming" of Indigenous lands (80-83) for European invaders.

It is against this context of research-as-colonization, that Aileen MoretonRobinson (forthcoming) insists that Indigenous research, "undertaken for and with our communities," is an assertion of Indigenous sovereignty. It is a decolonizing act, insofar as it claims for Indigenous peoples the "sovereign right to determine our research agendas informed by our politics and our commitment to social justice for our people." Indigenous research is, in short, an unashamedly political project, but one with many other dimensions, at once inextricably economic, cultural and spiritual. As Makere Stewart-Harawira emphasizes, Indigenous research may only be properly understood in holistic terms, rooted in an openness to all aspects of individual and human collective experience. This may typically include an important and explicit role for intuition, dreams and ceremony that are often excluded from textual accounts of highly-codified colonial science, even when they inform western research in practice. At the same time, enacting such Indigenous practices is a way of valuing and renewing Indigenous knowledges discredited through colonialism. Indeed, in his contribution, George Sefa Dei argues that Indigenous research is "a complex decolonized approach of producing, interrogating, validating and disseminating knowledge based on Indigenous peoples' cosmology/worldview or 'worldsense'."

Emphatically, this does not mean the appropriation and incorporation of fractions of Indigenous knowledge into pre-existing Enlightenment models of science - as, for instance, with the decontextualized absorption of aspects of Indigenous spiritual and 
natural knowledge into "Traditional Ecological Knowledge" as part of narrowlyconceived environmental assessment procedures (Simpson 2001). Such approaches distort Indigenous meanings by presenting what Stewart-Harawira refers to as "partial truths," truths devoid of context. The real sense and significance of such partial truths is obscured, since their meanings are only made properly apparent when placed within specific, ethical relationships governing the communication of knowledge and embedded within corresponding worldviews. Instead of being ripe for piecemeal appropriation by mainstream research, Indigenous research should be understood as one site for the integrated praxis of Indigenous ways of being, knowing and doing. This may include a range of approaches unfamiliar to mainstream colonial research, including the painstaking cross-referencing of centuries-old knowledge expressed through stories, chants and songs - and exactly what cross-referencing 'makes sense' and should be prioritized may only be clear within specific Indigenous worldviews and moral commitments. Through such Indigenous research, Indigenous peoples who have long been the stigmatized "objects" of the expert colonial gaze participate as sovereign actors of their own histories in the academy, using research to answer questions that matter to their communities.

\section{'Good' and 'Bad' Science}

Of course, many scholars working within mainstream social scientific paradigms reject the claims implicit in the idea of 'decolonizing research' and related terms like 'colonial social science'. They insist that there is no such thing as colonial and Indigenous science but only 'good' and 'bad' science. The point of research, they argue, is to arrive at universal truths or at least to rigorously use scientific methods that have proven realworld results, not forward a political agenda of any sort. Indeed, they worry that an explicit political agenda for research will warp the relentless pursuit of objective truths at the heart of the scientific endeavour. Moreover, they fear that research, understood as an expression of Indigenous sovereignty, may result in the exclusion of non-Indigenous researchers from research about and with Indigenous communities. They regret the potential loss of access to previous 'fields' in which they were experts - and this is a reasonable concern, insofar as some Indigenous communities have banned researchers while many others have placed increasingly important restrictions on access (Tuhiwai Smith 2004, 178). Further, many mainstream social scientists ask why a researcher's 'racial' identity as settler or Indigenous matters, arguing that the only criteria worth considering is the merit of the scientist and the scientific project.

While acknowledging that social scientists have sometimes, even often been complicit with colonialism, mainstream researchers observe that many non-Indigenous social scientists have, in fact, worked cooperatively over many years with Indigenous peoples. In this capacity, social scientists have played a vital role in documenting and so 
helping to preserve Indigenous knowledges and ways of life threatened by colonialism. For instance, the supportive role of archaeologists and anthropologists, among others, as legal witnesses for Indigenous land claims suggests scholarly solidarity with Indigenous struggles rather than domination over Indigenous peoples, including by 'settler' academics. This implies that traditional mainstream forms of research, as a specific, rigorous way of understanding the world, are not oppressive but in fact useful to Indigenous communities. Finally, there are concerns that as a consequence of Indigenous concerns about mainstream science, non-Indigenous researchers are being "policed", even subject to law suits because of their research. Whether realized or not, such political pressures dangerously interfere with fundamental academic freedoms to write and speak the truth as social scientists understand it.

\section{Indigenous Research: From Margins to Centre}

Many Indigenous researchers counter these arguments and concerns, not as the central aim of their scholarship, but as a way of explaining the contours of Indigenous research to those more familiar with mainstream social science. Of course, the necessity of doing this suggests the ways that Indigenous research speaks "from the margins to the centre" to use bell hooks' phrase (2000). Indigenous researchers must routinely explain and justify their approach against standard scientific theories and methodologies, while non-Indigenous researchers do not typically have to explain and justify their assumptions. Even when writing about Indigenous concerns, for instance, non-Indigenous researchers are compelled by no professional standards to explain why they do not adopt Indigenous research paradigms. Moreover, there is neither prestige nor academic rewards attached to such reflexivity by non-Indigenous researchers who may even be professionally chided for centering "minor" concerns about Indigenous worldviews in their scholarly work. At the same time, for Indigenous scholars, a certain fatigue results from the continual need to explain Indigenous approaches against established research. Within the university, furthermore, Indigenous scholars may find their academic employment and career advancement threatened since research centering Indigenous concerns and approaches is devalued as "objectively" concerned with "minor" issues, published in objectively lowerranked, "minor" specialized journals and presented at "minor" specialized conferences (see Smith 1999, 37-44, for a description of such processes for feminist researchers). Indigenous research may not even be recognized as such or may be dismissed as folklore rather than science. Indeed, as Stewart-Harawira observes, recent attacks on Indigenous research maintain that only Indigenous research that meets western criteria of validity should be considered science, making the idea of specifically "Indigenous" research redundant.

This institutionalized de-centering of Indigenous perspectives, MoretonRobinson argues, is at once a scientific and political problem since it masks the 
specificities of non-Indigenous research and the imperial ambition that disguises historically specific colonial science as universal truths. Against such claims to universal, scientific truth, Moreton-Robinson draws on feminist Sandra Harding's (2004) standpoint theory to argue that there is no such thing as universal, much less value-free science. This position echoes relativist debates in its insistence on the existence of multiple and incommensurate ontologies, epistemologies and related methodologies. But it is not straightforwardly relativist, because underlying Moreton-Robinson's argument is a story about science as the exercise of political power and even as a form of violence. She maintains that the dominant paradigm's exclusive claim to universalism and expert scientific truth-telling is a powerful way of disqualifying and marginalizing Indigenous (and other subaltern) ways of beings and knowing. Against this universalistic claim, Moreton-Robinson lays bare the unstated premises of mainstream research - and it is arguably because she writes from an Indigenous perspective that she is well-equipped to do this.

Moreton-Robinson maintains that what masquerades as universal science - what she calls the view at once "from everywhere and nowhere" - is in fact as "shared, situated, relational, multiple, complex and contextual" as Indigenous women's worldview. Specifically, mainstream, patriarchal social science is premised upon what MoretonRobinson refers to as a "new age" version of the Cartesian model. This model assumes a radical separation between mind and body, objectivity and morality and, it might be added, between the human, natural and spiritual worlds. These particular assumptions of mainstream research only appear universal, rather than historically and culturally specific, because they are so dominant that they have become the commonsensical standards for understanding what constitutes (good) science. Yet, in fact, mainstream social science is neither a view from nowhere nor everywhere, but rooted in specific, binary ontological and epistemological commitments, assuming radical oppositions between mind/body, objectivity/morality, man/nature and nature (or materiality)/spirituality that are rejected by many Indigenous peoples, among others. Of course, not all western science accepts these binaries. But even mainstream sciences that specifically investigate, for instance, the mind-body connection as in some branches of neurology, eschew reflexive consideration of the ways that the researchers own scholarship may be informed by the researchers' own mind-body connections (the mind-body connection is understood as the object of research, not as informing research processes).

It follows that if there is no such thing as 'universal' science, then there is no problem-free and obvious way of deciding what is science, much less what is good science. Instead, the very definitions of what constitute good and bad, acceptable and unacceptable science and the criteria for what constitutes a meretricious scholar and worthy scholarly project, depends upon underlying conceptions of being, of knowing and of basic moral commitments. Indigenous ways of answering these questions, including regarding what constitutes a worthy, meaningful social science project, have not been 
taken seriously under colonialism. Yet, this state of affairs is the result of the historical accident, many might say nightmare, of colonialism and need not be so. In the meantime, Indigenous communities and Indigenous scholars are not waiting for academia to grant this - they are already asserting their rights to make these scientific judgements for themselves. As Stewart-Harawira observes, for instance, Indigenous communities have taken seriously chants and oral histories as a source of centuries-old knowledge, an approach that has critically informed successful efforts to improve the water quality of polluted streams. Moreton-Robinson's own research contributions have been importantly grounded in her connections to specific features of Quandamooka country, which she understands as imbued with the spirits of her ancestors. This knowledge enabled her, for instance, to intuit as non-Indigenous a book purporting to be from the perspective of an Indigenous woman, before it was formally unmasked as the product of two settler men. From her standpoint as an Aboriginal woman, it was evident that the book's outlook was curiously detached from relations to rootedness in the land and natural environment, in a way foreign to Aboriginal ontologies. Such Indigenous approaches to research represent a (healthy) challenge to mainstream social scientists, implicitly requiring them to make explicit their own research premises, including the ontological and epistemological but also moral commitments underlying their research.

George Sefa Dei answers to other concerns expressed by mainstream social scientists. In his contribution, he writes that he is "unapologetic" when he states bluntly that, "the days of Non-Indigenous peoples becoming 'experts' on Indigenous peoples are long over." Like Moreton-Robinson, he maintains that non-Indigenous scholars are not the arbiters of what constitutes truth, meaning and science for Indigenous peoples; only Indigenous peoples hold this power. This is true, moreover, because Indigenous peoples have always been doing research, in the sense of searching for knowledge and communicating that knowledge to others. Often, Dei points out, this has been done in ways not recognized as research in mainstream traditions, including storytelling but also attentiveness to ancestors and the natural and spiritual world in ways that moreover inform everyday survival. Hence, Indigenous peoples never ceased to be experts within their own communities about their own experiences.

Of course, not all Indigenous peoples and Indigenous scholars hold the same worldviews and as Dei points out, this means there is controversy about what exactly constitutes Indigenous research as opposed to research carried out by Indigenous people. Moreover, Indigenous scholars may write in ways that are thoroughly colonial in approach, methods, values and writing style (see also Tuhiwai Smith 2004) - either because they have assimilated dominant viewpoints or because they have adopted these strategically for the purposes of communicating Indigenous concerns to non-Indigenous expert audiences. The point is that non-Indigenous peoples, including credentialed experts, do not have the authority - although historically they have acted as if they did - 
to decide these vital questions for Indigenous communities, even in the name of a supposedly disinterested universal science.

This does not mean that Indigenous research is a totalizing project, seeking to take over the academy and make Enlightenment forms of social science disappear. In the first instance, some Enlightenment methods of science might be usefully appropriated by Indigenous peoples as they seek to answer questions that matter in their communities and strategically as they seek to convince a public unversed in Indigenous research. More profoundly, Dei argues, a uniquely Indigenous science is unrealistic even if it were desirable: co-existence between Indigenous and non-Indigenous peoples is a fact and this implies the ongoing co-existence, the mutual influencing and transformation of different forms of both Indigenous and non-Indigenous research. The issue is the terms of that coexistence, which Dei maintains must be based on the political meeting of equals. If Indigenous communities feel this premise cannot be met, then they may refuse access to their communities by non-Indigenous (and even some Indigenous) researchers. But this should not be understood as a taking away a prior right to 'access', since non-Indigenous researchers never had the unfettered right to move and work within sovereign Indigenous communities, despite the conventions and practices of colonial administrations that assumed and assume otherwise.

\section{The Violence of Social Science Research}

Within the strictly scholarly realm, this premise of political (and human) equality means that Indigenous peoples can no longer be treated, as Dei puts it, as "mere descriptive appendages to theoretical formulations." Treating other human beings as mere "data," all the while deriving credentials, academic esteem and prestige from this research activity, is, in this view, an immoral act of violence and exploitation. Moreover, historically many non-Indigenous representations of Indigenous peoples have been very damaging, with the explicit or implicit aim of reproducing and comforting colonial justifications for rule over Indigenous peoples. Indigenous peoples may understand concerns about the academic freedom of non-Indigenous researchers, but argue that these considerations about academic careers pale against the contemporary stakes of research for Indigenous communities. These stakes include not only Indigenous wellbeing but literally Indigenous survival given the still-credible threat of genocide through assimilation in many colonial contexts. The academic freedom of nonIndigenous researchers, they argue, can only be a secondary consideration to the primary concern of ensuring Indigenous peoples' sovereignty as a necessary condition for continued Indigenous self-expression and existence as Indigenous peoples.

Granted the full sovereignty of Indigenous peoples, however, there is no reason, in principle, that non-Indigenous researchers, like myself, can't sometimes work with and for Indigenous communities, as indeed settler researchers sometimes have in the past. 
This has to be done cautiously, because of the risk of misinterpretation by nonIndigenous scholars of Indigenous worldviews and because even sincere efforts at solidarity may reproduce relations of domination. For instance, white anthropologists who testify on behalf of Indigenous land claims do not play an unambiguous role. Rather, their "support" is strategically necessary in a context in which settler justice systems (at once party and judge in treaty disputes) do not recognize Indigenous expertise; hence white anthropologists are enacting and reproducing a "white expert" role at the same time as they seek to show solidarity with Indigenous land claims through their testimony. Of course, it is a symptom of the colonial disregard for Indigenous knowledges that 'white' experts are frequently treated as more reliable and authoritative interlocutors about the Indigenous experience than Indigenous peoples, including Indigenous scholars, themselves. Undercutting this is a constant problem. Indeed, this article can be read as a 'white expert' interpretation of Indigenous scholarship, as if the Indigenous scholars whose work I describe cannot speak adequately, eloquently and forcefully on their own behalf. That this is not my intention does not moot the danger, although by alerting readers to this I can arguably circumscribe my own (limited) authority.

The point is that decolonizing scholarship does not mean that no cooperation between Indigenous and non-Indigenous peoples and scholars is possible. Rather, the reality of the ongoing colonial context means that the underlying principles guiding any cooperation with Indigenous peoples must be the Indigenous 'rules of engagement', as Moreton-Robinson puts it, for that relationship. Non-Indigenous scholars who reject this as a capitulation to political correctness forget that their own approach is just as political, but instead insists upon a non-Indigenous baseline for all research collaborations. Given the historical complicity of social science with colonialism, the burden of proof regarding the value and morality of mainstream science is now on non-Indigenous researchers. In the meantime, Indigenous scholars are carrying out research in ways coherent with their worldviews and commitments to social justice for their communities. As StewartHarawira points out, this means a constant negotiation between the researcher, whether Indigenous or not, and the Indigenous community so that research may be halted or carried on, but on an altered basis given new concerns expressed by the Indigenous community about the research process. On this basis, George Sefa Dei argues, Indigenous research by and for Indigenous communities may become a site of healing, including potentially renewed Indigenous-settler relationships.

\section{Revitalizing Indigenous Scholarship}

Unsurprisingly, Indigenous research faces strong challenges from dominant social scientific approaches. In such mainstream paradigms, nature is an exploitable resource, rather than a sacred source of life that vitally informs how and what we know, even what questions are worth asking. Relations with the land, water and non-human life often 
appear as irrelevant to much social science research and how it is carried out. Dominant research paradigms emphasize and privilege the role and words of credentialed researchers at certified academic institutions. Authority is gained through degrees, through written texts and oral presentations at academic ceremonies known as conferences, and through titles conferred by certified institutions, as well as through footnotes, references and peer appraisals by other similarly credentialed professionals. In Anglo-Saxon countries in particular, pressures on university research within a context of neoliberal austerity politics means reduced public funding for research and increased reliance on private sources, often driven by underlying commitments to research that supports the generation of profits and that understands research as "intellectual property". Thus, as Stewart-Harawira points out, the historical moment is not particularly propitious for Indigenous research that has no obvious connection, and may in fact counter the priorities of profit-seeking private funders that increasing orient research agendas.

Although it is difficult to make statements across quite different Indigenous traditions, a few generalizations may be hazarded. Thus, for instance, Cree-Métis scholar Emma LaRocque insists on the ways that Indigenous research and teaching moves "from land to classroom" (2000), emphasizing the vital ways that connections to the natural world inform Indigenous research. In her own research, Aileen Moreton-Robinson observes the critical importance of meditation on the wisdom of ancestors in sacred places and underscores her deliberate privileging of the voices and words of Indigenous peoples, especially Indigenous women. In Indigenous research, authority may come from specific, privileged relations with the spirit world and relations with other Indigenous peoples rather than formal credentials. As in the late Haudanausee scholar Patricia Monture's work, footnotes may refer to the orally transmitted words of "my grandmother" (Monture-Okanee 1992, 240) and the wisdom of Elders, rather than to $\mathrm{PhDs}$ in anthropology whose words are sacralised in mainstream paradigms only once they are written down in specific textual forms. Much Indigenous research is oriented by a strong commitment to social justice within Indigenous communities rather than answering externally-funded profit-making agendas, while the notion of "intellectual property" is rejected in favour of the transmission of knowledge in specific, often face-toface, relationships.

In this and other ways, Indigenous research challenges the assumptions and conventions of mainstream social science. Of course, Indigenous research is not the only significant challenge of this kind. Other dominated communities and classes have challenged dominant social scientific ontologies and epistemologies. For instance, Black feminist Patricia Hill Collins (2009) emphasizes the wisdom - as opposed to credentialed 'knowledge' - of Black women, including that of the schoolgirls, former slaves, preachers and family members' she draws upon in her work. Collins counters abstract, theoretical knowledge that values "objectivity" with an argument for a Black feminist social science 
rooted in lived experiences and informed by an ethics of caring, personal accountability and dialogue (260-290). Like this Black feminist approach and other counterhegemonic approaches to social science, Indigenous researchers offer a "standpoint" from which the fundamental assumptions of mainstream social science are laid bare. These assumptions may be defended, but even in such cases, Indigenous approaches have the merit of making dominant social science paradigms' underlying ontological, epistemological and methodological assumptions explicit, especially naïve postivist and post-positivist approaches with their assertions about the human capacity to directly grasp an objective social and material world.

Worldwide, there is a movement of Indigenous resurgence, although this is taking place unevenly and is not without important internal contradictions and recent challenges. Thus, if the emergence of Indigenous research reflects gains from broader political struggles by Indigenous peoples in the 1960s, as Stewart-Harawira describes, current attacks on Indigenous sovereignty suggest greater challenges are ahead for Indigenous research. In Canada, for instance, the federal government recently passed legislation that unilaterally rewrote colonial-Indigenous relations as set out in the (highly problematic) Indian Act, while simultaneously facilitating the opening-up of Indigenous lands for the primitive accumulation of capital through resource exploitation by private corporations. Such basic attacks on Indigenous sovereignty vitally threaten Indigenous connections to the natural world upon which Indigenous ways of knowing, being and doing are based. The recent Indigenous-led Idle No More movement in Canada, which arose in response to these threats suggests the vibrancy of ongoing Indigenous resistance. But this new, aggressive moment of age-old processes of colonial lawmaking over Indigenous peoples and of capital's restless incursion onto Indigenous lands in search of profits poses serious threats to Indigenous wellbeing. Inevitably, this will affect Indigenous research that depends for its ongoing existence upon the strength of the Indigenous community outside of the academy. Moreover, within the university, as Stewart-Harawira decribes, Indigenous research is being marginalized on the grounds that it is not marketable, while fractions of Indigenous knowledge are being integrated in a piecemeal way into for-profit research projects - sometimes as "intellectual property" so destroying the holistic approach integral to Indigenous research and transforming Indigenous knowledge into a commodity that may be bought and sold like any other commodity.

Still, there is what might be called an "Indigenous revolt" (Le Bot 2009) or Indigenous resurgence (Alfred 2005, 179-286), taking both institutional forms, like the 2007 signing of the United Nations Declaration of Indigenous Rights, and less formal shape, like the Idle No More movement and associated efforts like the teaching of Indigenous languages that may be less obvious outside Indigenous communities. As Tsalagi (Cherokee) scholar Jeff Corntassel has put it (2013), this process of Indigenous resurgence is one of seeking to "live in a longer now" through the decolonizing praxis of 
remembering and renewing histories and cultural traditions through relations with sacred homelands and waters. This decolonization confronts, as it has in the past, the often brutal takeover of Indigenous lands by capital with the backing of colonial states. Thus, living these remembered and renewed relations with the natural world requires bitter political battles, upon which the continued development and practice of specifically Indigenous ways of being, and doing - and so Indigenous research - depends.

Indigenous research represents both a challenge and a possibility for mainstream stream research, unmasking the assumptions of colonial research and so potentially opening up new ways of thinking about and doing research. Ultimately, however, whether or not mainstream social science is unsettled by Indigenous research is secondary to the immediate importance of Indigenous research for Indigenous communities themselves. Historically, social science has been an expression of the colonial project; now, for many Indigenous communities, Indigenous research is becoming one site for the affirmation of Indigenous peoples as actors, rather than objects, in social science research. In other words, I have argued that Indigenous research matters for traditional social science; but the broad social significance of Indigenous research is that it is one way that Indigenous peoples are affirming their authorship of their own histories as Indigenous peoples, shaping rather than submitting to history. Whether or not Indigenous researchers succeed, however, is ultimately not an academic question. Instead, it rests upon how robust movements for Indigenous sovereignty are outside of and within the academy.

\section{References}

Alfred, Taiaiake. 2005. Wasàse: Indigenous Pathways of Action and Freedom. Peterborough: Broadview press.

Corntassel, Jeff. 2013. www.contassel.net. Accessed May 2013.

Deloria, Vine Jr. 1998. "Comfortable Fictions and the Struggle for Turf: An Essay Review of The Invented Indian: Cultural Fictions and Government Policy." Pp. 65-83 in Native and Academics: Research and Writing About American Indians. Edited by Devon A. Mihesuah. Lincoln: University of Nebraska Press.

Harding, Sandra, editor. 2004. The Feminist Theory Standpoint Reader: Intellectual and Political Controversies. New York: Routledge.

Hill Collins, Patricia. 2009. Black Feminist Thought. New York: Routledge. Second edition. 
hooks, bell. 2000. Feminist Theory: From Margin to Centre. Cambridge: South End Press.

LaRocque, Emma. 2010. When the Other is Me: Native Resistance Discourse 1850-1990. Winnipeg: University of Manitoba Press.

LaRocque, Emma. 2000. "From the Land To the Classroom: Broadening Aboriginal Epistemology." Pushing the Margins: Native and Northern Studies. Edited by Jill Oakes et al. Natives Studies Press.

Le Bot, Yvon. 2009. La Grande Revolte Indienne. Paris: Robert Laffont.

Monture-Okanee, Patricia A. 1992. "The Roles and Responsibilities of Aboriginal Women: Reclaiming Justice." Saskatchewan Law Review. 56:237-266.

Moreton-Robinson, Aileen. Forthcoming. Towards an Australian Indigenous Women's Standpoint Theory: Relating Experience, Power and Knowledge Within Indigenous Research.

Simpson, Leanne. 2001. "Aboriginal Peoples and Knowledge: Decolonizing our Processes.” The Canadian Journal of Native Studies. (21) 1:137-148.

Tuhiwai Smith, Linda. 2004. Decolonizing Methodologies Research and Indigenous Peoples. London: Zed Books. Second edition. 